\title{
LEISURE GARDENS, SECULAR HABITS: THE CULTURE OF RECREATION IN OTTOMAN DAMASCUS
}

\author{
Samer AKKACH
}

Received: 04.01.2009; Final Text: 24.03.2010

Keywords: Al-Nābulusī; Damascus; garden; recreation; poetry; Ottoman; early modern.

1. Al-Budayrī (1997, 193-4).
Leisure gardens and the culture of recreation associated with them have long been an integral part of urban life in Middle Eastern cities. Yet only little has been uncovered on urban landscape history and associated spatial practices in provincial Ottoman centres. Our knowledge of this aspect of socio-urban life has thus remained limited. This is mainly due to the paucity of information on urban landscape in conventional historical sources, and the disappearance of most gardens from the cities' fabric during the rapid expansion of modern urbanisation in the nineteenth and twentieth century. This study attempts to shed fresh light on leisure gardens and the culture of recreation in Ottoman Damascus in the seventeenth and eighteenth century. It explore the topic through an unconventional source: an anthology of poems by a leading mystic, 'Abd al-Ghanī al-Nābulusī. Titled the Wine of Babel, this hitherto unexamined source documents the recreational activities of a unique religious personality, whose poetry and other notations offer valuable insights into this vivaciously expressive aspect of urban life. While his notes give us the names of many gardens and places of recreation, which no longer exist, his poetry enable us to gain insights into the aesthetic sensibility of the period. This paper focuses on the aesthetic sensibility revealed in his poetry by tracing, on one hand, the ways in which poetic imageries and figurative expressions were used to map emotive experiences over specific visual fields, and, on another, the role gender played in determining the general aesthetic attitude towards nature and landscape among the educated elite in the Damascene society.

\section{Introduction}

In his chronicle of daily life in Damascus (Hawädith Dimashq al-Yawmiyya), eighteenth-century diarist-historian Aḥmad al-Budayrī al-Ḥallāq describes many curious events, one of which depicts a recreational outing that took place in $1163 / 1750(\mathbf{1})$ : 


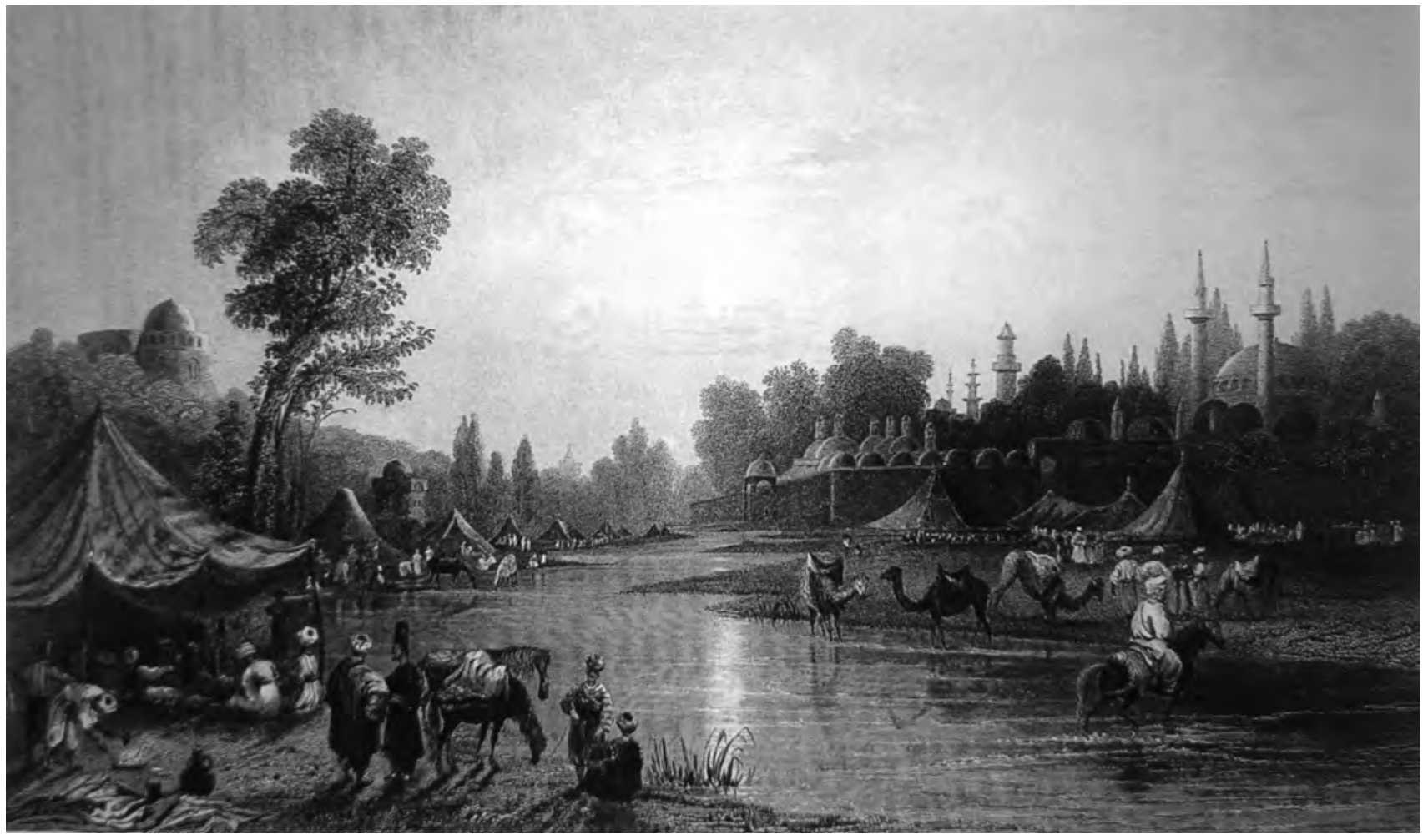

Figure 1. William Henry Bartlet, The River Barada, The Ancient Pharpar, engraved on steel by S. Lacy 1936. (www.antique-prints.de)

2. Conventional historiography of the Middle East considers the early modern period as coinciding with the systematic exposure to Europe in the nineteenth century. In the Arab world this is commonly known as the Arab Awakening, which Hourani (1962) calls the age of liberal thinking. This view normally leaves the preceding two centuries as an ambiguous period. In my study (2007) I have argued that there was an earlier phase to the exchange with Europe that was not based on a wholesale adoption of the Enlightenment ideas. It is this phase that I am referring to here as early modern. There are other studies that support this view, see, for example, Gran (1998); and Hanna (2003).

3. Al-Budayrī's as well as other contemporary historians, such as al-Jabartī and Ibn Kannān, relate many such stories which reveal the social transformation taking place at that period. For more details on this, see Sajdi (ed. (2007) and Hanna and Abbas, eds. (2005).

4. This is probably al-'Izziyya School; for details on the location of this school, see Al‘Ulabī (1989, 199-200).

5. This architectural complex, still extant and in a reasonable condition, is attributed and Sultan Sülaymān and the architect Sinān. It currently has a mosque, a military museum, and a handcraft market. Al-Salīmiyya, also still extant and in a reasonable shape, was the first Ottoman religious complex ordered by Sultan Salīm upon his takeover of Damascus to be constructed over the tomb of Ibn 'Arabī in al-Sālihinyya.
“On Thursday the eighteenth of Rabī' al-Awwal (26 February), we went out together with some of our loved friends for a picnic on the high plateau (al-Sharaf) that overlooks the Marjeh. The time was the beginning of the blossom season. We sat there overlooking the Marjeh and the Takiyya alSalimiyya, and we were surprised to see more women than men sitting on the side of the river, eating, drinking coffee, and smoking, as men usually do. This is something the like of which we have not heard of happening anywhere until we witnessed it ourselves."

Al-Budayrī's note gives an intriguing glimpse of the daily life and urban recreational practices in early modern Damascus (seventeenth and eighteenth centuries) (2). His expressed surprise at the unusual way in which women were entertaining in public, "as men usually do," is indicative of the emerging new social habits in Damascus as well as in other cities in the region (3). About eighty years later, English traveller and illustrator William Henry Bartlett (1809-1854) visited the same area described by al-Budayrī and captured it graphically in a famous drawing titled The River Barada, The Ancient Pharpar.

Bartlett's picturesque drawing shows a large Ottoman building to the right and a small domed building located at a higher ground to the left (4). It is at that higher level where al-Budayrī was most likely sitting together with his friends, overlooking the famous Baradā river and the Ottoman building, which he referred to mistakenly as al-Takiyya al-Salīmiyya rather than al-Takiyya al-Sulaymāniyya (5). Along the river, Bartlett shows a long, dense row of tents extending on one side and fading into the horizon. At the foreground, Bartlett depicts the details of a tent sheltering a group of resting men, before whom another group seems to be going about their busy daily activities, all are situated in a beautifully constructed landscape. On the other side of the shallow river, next to the Ottoman building, several large tents also appear bustling with people and activities. Women 
6. See Hamadeh (2008).

7. Al-Badrī (2006).

8. Mubaidin (2009).

9. Al-Budayrī $(1997,171)$. The word "secular" is not used here in the Western sense of "non-religious" or "anti-religious," but rather in the sense of "worldliness," meaning "preoccupation with worldly matters," whereby the "religious" is not necessarily excluded.

10. "Feminine Virtues" were sought and appreciated not only in women but also in young beardless boys. For details see references cited below in note 40 . The nature of love and the beloved were the subject of intense debate around that time, see AlNābulusī (2007).

11. The anthology was edited by Al-Jundi (1988). Substituting Khamrat with Burj (tower), and ghin $\bar{a}^{\prime}$ with shadwu (chirping), reflects a desire to avoid the reference to "wine" and "singing" in the title. Hereafter I will refer to the anthology by its published title.

12. Al-Nābulusī $(2007,18)$. These gatherings, which were held between $1085 / 1674$ and $1120 / 1708$, were generally restricted to a close circle of friends and relatives, but were sometime expanded by joining other groups who happened to meet at one place. are noticeably absent in Bartlett's drawing, yet we do not know the exact circumstances of the drawing, nor do we know enough about the culture of urban recreation in Damascus to reconcile al-Budayrī's textual and Bartlett's graphic representations. From the historical sources of the period, however, we know that this was a popular site of urban recreation, which was commonly frequented by members of the Damascene society. We also know that an outburst into the public realm associated with significant socio-urban transformations was taking place in this as well as other Ottoman centres, and particularly in the capital Istanbul (6).

Leisure gardens and the culture of recreation associated with them were important spaces of public sociability, which have long been an integral part of urban life in Middle Eastern cities. Recreational outings (tanazzuh, in Arabic), family picnics, and group gatherings in private and public gardens were common in Damascus, as a famous fifteenth-century source (Nuzhat al-Anām fì Maḥ̄āsin al-Shām) indicates (7). Smoking, coffee drinking, class and gender mixing, singing, and entraining in public, however, were among the new socio-urban habits that emerged in many Middle Eastern cities in the sixteenth and seventeenth centuries, causing much debates, tension, and social unrest. These can be traced in several historical sources and have been the subject of new studies (8). In the same chronicle, al-Budayri exposes other aspects of the Damascene "secular" urbanity that began to take root in the city, which he associated with "the rise of corruption and injustice, and the increase in the number of prostitutes present in marketplaces during daytime and at night" (9).

\section{The Wine of Babel}

In Damascus, as in other Middle Eastern cities, there were always urban spaces dedicated to pleasure, recreation, and entertainment. Yet in the seventeenth and eighteen century, as we have seen, new worldly habits emerged and began to change the dynamics of social interactions. While the boundaries defining social hierarchy became increasingly permeable, certain grouping maintained distinct social identity. The social elite members of notable families, government officials, eminent scholars- for example, continued to gather regularly in the city's private and public gardens for entertainment and social recreation. Their main form of entertainment was spontaneous yet sophisticated poetic exchanges. According to the records of some of these gatherings, women were absent from a certain type of men-only outings. In these gatherings, the absence of women was compensated by the exchange of amatory elegies and love poetry that often mapped feminine virtues of the beloved over the landscape (10). The appreciation of nature's beauty was thus mediated by poetic imagery celebrating femininity and revealing men's effeminate languishing character, which was often concealed in the presence of women. The Wine of Babel and the Singing of Nightingales (Khamrat Bābel wa Ghin $\bar{a}^{\prime}$ al-Baläbel) is an anthology of such poems compiled by a leading literary and religious figure of the period, 'Abd al-Ghanī al-Nābulusī (1641-1731) (11). It features a large collection of poems by 'Abd al-Ghanī himself and his close friends recorded over a period of thirty-five years. A three-line poem cited in the anthology describes one of these gatherings as including a composer (of poetry), a singer, a writer, and a listener. This indicates that the recording of poems composed impromptu and sung in these gatherings was part of the rituals (12). 'Abd al-Ghanī, as the central figure and principal composer, collected these notes and assembled them in a single volume in the later part of his life (13). 
13. After $1096 / 1684$ the introductory comments to the poems changed from first to third person, indicating that the later part of the anthology was completed by someone else. The published edition gives no completion date, thus making it difficult to determine whether this relatively small section, which nonetheless covers twentyfour years of activities, was completed during 'Abd al-Ghanī's life or after his death. At the last dated recording 'Abd al-Ghanī would have been seventy years of age, that is, twenty-three year before his death.

14. As Chris Fitter $(1995,9)$ observes in Poetry, Space, Landscape: "No landscape can ever... be 'autotelic' - bearing a perennial and 'objective' appearance and significance independent of its reader: cultural projection by a landscape's beholder will complete its necessarily partial 'self-formulation'."

15. There are only two recently published accounts on the life and works of 'Abd alGhanī: Akkach (2007) and Siyyriyeh (2005).

16. Of his large body of works only fiftythree have been published; for details, see list of al-Nābulusī's published works in Akkach (2010, 365-87)

17. On his Sufism see Barbara Von Schlegell (1997) and Bakri Alddin (1985).
The anthology provides ample poetic references to the landscape and natural settings of these gatherings, identifying most of the palaces by name and location. Apart from a few distant places, all the gardens mentioned, public and private, were within or on the perimeters of Damascus' urban environs. Thus, in addition to its literary value of revealing the aesthetic sensibility of the period, and its social value of showing how the poetic presence of femininity was celebrated in the physical absence of women, the anthology has a historical value as an urban record of Damascus. It presents an image of the city's early modern urbanity that has been completely effaced by the rapid expansion and modern urbanisation of the twentieth century. Although the names of the suburbs and places cited are mostly identifiable in today's urban formation of Damascus, virtually all of the gardens and recreational places mentioned have disappeared. It is therefore not possible to match any of the poetic descriptions with the actual landscaped and natural settings in which they were composed. It is possible, however, to analyse the poetic descriptions of these places as a base for reading Damascus' urban landscape history, and to explore the nature and significance of the social practices associated with them. It is also possible to gain insights into the aesthetic sensibility of the period, by tracing, on one hand, the ways in which poetic imageries and figurative expressions were used to map emotive experiences over specific visual fields, and, on another, the role gender played in determining the general aesthetic attitude towards nature and landscape among the educated elite in the Damascene society. These will be explored later on, however, first we need to know who 'Abd al-Ghanī al-Nābulusī is, what his social status was, and why his anthology of poetry is selected to discuss aspects of Damascus' urban landscape.

\section{'Abd Al-Ghanī: A Master of Two Worlds}

'Abd al-Ghanī al-Nābulusī, one of the most prominent Muslim figures of seventeenth- and eighteenth-century Damascus, presents, through his personality, life style, and teachings, an expressive example of the socio-cultural, religious, and intellectual changes of his period. His social, religious, and spatial practices reflect a unique personality that embodies an unusual confluence of secularity and religiosity, rationalism and mysticism. Understanding his personality would, therefore, help us understand some of the personal and socio-cultural parameters of his poetic imagination as well the wider context in which he lived (14).

Born in Damascus in 1641, 'Abd al-Ghanī was a major Muslim polymath, whose complex and colourful personality is slowly being uncovered (15). Recognised as a Sufi master, a theologian, a hadith scholar, a historian, a traveller, and a poet, researchers find it difficult to capture the true depth and breadth of his contributions and influence from a single perspective without being reductive. A prolific author of over 280 works, 'Abd alGhani made significant contributions to several disciplines; his main domain of influence, however, was religious sciences (16). His conspicuous affiliation with Sufism is behind his current monochromatic image as a Sufi saint (17). Sufi saint though he was, his thought and teachings had much more to them than Sufism. His multifaceted personality and teachings reflect several aspects of the intellectual, social, and institutional changes of his time.

Through his personality, 'Abd al-Ghan̄ presented a new individualistic model of a self-made Sufi master, one who relied on texts rather than 


\section{Al-Nābulusī (1986).}

19. Muhammad Kamāl al-Dīn al-Ghazzī (MS 281). In my book I disputed the accuracy of al-Ghazzi's narrative on this point (Akkach, 2007, 36-9).

20. According to the dates of the recordings, 'Abd al-Ghanī must have written almost half of the anthology by $1085 \mathrm{~h}$, that is, by the age of thirty-five. This is not certain, however, because his citations are not always eventrelated. In fact in many cases it is clear that poems written on different occasions are cited together for thematic connection.

21. For a detailed discussion of these points, see Akkach, (2007, Part 2).

22. Al-Nābulusīs prided themselves on their ancestral lineage to two eminent roots: the Jamā'a and Qudāma families. Through the Qudāma family they trace their genealogy back to the Prophet's companion and second Caliph 'Umar b. al-Khațțāb (d. 644). Both the Qudāma and Jamā'a families are associated with the city of Jerusalem, and are often referred to as al-maqādisa, "the folks from Jerusalem." The family name al-Nābulusī, "the one from Nāblus," however, identifies the family with the Palestinian city of Nāblus, a historic town of Roman origin located about sixty-three kilometers north of Jerusalem. The new appellation refers to a brief stay of 'Abd al-Ghani's ancestors in the city of Nāblus while on their way to Damascus, a reference that eventually eclipsed the reference to the familial roots.

23. Al-Nābulusīi in Al-Jundī, A., ed. $(1988,21)$ masters for spiritual attainment, and one who apparently saw no conflict between worldly pleasure and spiritual fulfillment. The engrossing sensuality of his poetry in The Wine of Babel, which is devoted to corporeal pleasure, stands in startling contrast to the transcendental spirituality of his poetry in The Anthology of Truths (Diwān al-Haqā'iq), which is devoted to mystical revelations (18). Both substantial anthologies seem to reflect concurrent experiences, paradoxical as they may seem, rather than different episodes of his life. According to his main biographer Muhmmad Kamāl alDīn al-Ghazzī (d. 1214/1799), from the age of forty-one to forty-eight (10911098/1681-1687), 'Abd al-Ghanī went into a seven-year spiritual retreat (khalwa), during which he isolated himself from social interactions (19). According to the dates recorded in The Wine of Babel, however, this lengthy spiritual retreat, if it was so, was interspersed with several social outings, during which he seems to have been able to switch his focus from heaven to earth in a remarkable way (20).

Through his teachings, 'Abd al-Ghanī attempted to expand the scope of the rationality of Islamic religious thinking. He articulated a philosophy of religion that supported an ecumenical and egalitarian understanding of Islam, enhanced its scope of tolerance, as well as introducing a philosophy of being as a viable alternative to the natural theology that was emerging in Europe. Through his public readings of highly controversial mystical texts, he also strove to create a new social space for mysticism, one that promoted public participation rather than privacy, secrecy, and elitism. His attempt to exploit the power of the public to counter the rising antimystical sentiment was unprecedented in Damascus, generating at once much interest and unease (21).

'Abd al-Ghanī descended from a family of religious scholars that included many eminent lawyers, but no Sufis. They were well-respected in Damascus and admired for their scholarly contributions (22). 'Abd alGhan̄i was the last eminent figure of the family, after whom the Nābulusīs' commanding intellectual presence rapidly vanished, thanks largely to the modern reform movements that emerged at the beginning of the nineteenth century, and cut intellectual ties with the preceding masters. Today, 'Abd al-Ghanī is only faintly present in the collective memory of modern Muslims. Very little has been written about him and most of his works are still in manuscripts buried in various libraries around the world.

\section{Publicity, Secularity, and Fame}

'Abd al-Ghanī rose to fame in Damascus at the age of twenty-five in one of those urban recreational gatherings, which tended to cultivate secular sentiment. In one of the first few poems cited in The Wine of Babel, 'Abd alGhanī openly expressed this sentiment:

Respond to the callers for youthful desires and support the group, and replace abstention from love with openly seeking pleasure.

And adhere to excessive desires and burning passion, and leave behind the words of advisers, and stop listening to them.

Only the brave wins the pleasure, while the coward and the hesitant fail to reach it.

Do not think that happiness will last; nor will sadness: endless as it may seem, it will come to an end (23).

The Wine of Babel was chronologically assembled, and the first dated recording indicates that 'Abd al-Ghan̄ most probably wrote these lines before the age of thirty-five. Yet, considering that he was already a 
celebrated Sufi at the age of twenty-five, it is difficult to reconcile the deep contradictions these lines reveal. Was this polarity particular to 'Abd al-Ghanī's personality, or was it representative of a wider trend in the Damascene society, are questions requiring more research before they can be answered adequately.

Through his father's connections, 'Abd al-Ghanī maintained contacts with the dignitaries, religious leaders, poets and distinguished personalities of Damascus. His name arose as a potential successor to his father, who died relatively young at the age of forty-five when 'Abd al-Ghani was only twelve, and he was often invited to join the regular recreational gatherings. Poetic exchanges, exhibiting wit, literary skills, knowledge, and imagination, were the main currency of entertainment. In one of these gatherings, 'Abd al-Ghanī took part in the poetic exchanges and recited a few lines of a long poem he had carefully composed. This led to him reciting more and more lines until he captured the attention of the audience. Members of the group were impressed by its sophistication and novelty, and, being unfamiliar with it, they inquired about its author. When 'Abd al-Ghanī said it was his, many were sceptical. They demanded a second recitation of the whole poem. Upon the second hearing most of the audience praised 'Abd al-Ghanī, yet a few remained doubtful. So that all doubts about its authorship might be resolved, he was asked to write a commentary on it. He agreed and asked for two weeks to complete his work, but the grandson of the Head of the Damascene Nobles, 'Abd al-Raḥmān Efendī, who was present at the gathering, gave him three weeks and invited everyone present to reconvene at his place to hear the commentary. As scheduled, the group gathered at 'Abd al-Raḥmān's house where 'Abd al-Ghani delivered his commentary that came in two forms: poetic and prosaic. The audience was just as impressed with the commentary as with the original piece and acknowledged 'Abd al-Ghanī's poetic talents (24).

'Abd al-Ghanī was a prolific poet, and later in his life he himself complied his poetry in a massive anthology (Diwān al-Dawāwinn), which he divided into four sections, one of which was The Wine of Babel (25).The main topics in this section were his recreational outings and the amatory poetry composed during these regular events. In these poems the visible natural settings and the invisible sensual and emotional overlays are obviously more important to us here than the stylistic and technical qualities of the poems. Contextualised, experiential depictions as they are, the poems are a valuable, albeit unconventional, source of information on Damascus' urban landscape history. Together with contemporary sources, such as Ibn Kannān's The Islamic Convoys (al-Mawākib al-Islāmiyya), and earlier sources, such as al-Badrī's The People's Stroll (Nuzhat al-Anām), alNābulusî's anthology forms a foundation from which a socio-urban history of Damascus' landscape can be constructed (26). A brief overview of Damascus urban environs and the culture of public recreation would help contextualise 'Abd al-Ghanī's experiences and poetic representations.

\section{Damascus' Beauties and Urban Recreation}

Damascus, often referred to as the oldest inhabited city, is characterized by a unique geography that provides an abundance of water despite its hot, arid and dry climate (27). The runoff from the snowy mountains in the east as well as many fresh water springs fed the city's main life line, the Barada river, which branches into several smaller rivers as it enters the
25. On 'Abd al-Ghanī's thoughts behind the compilation and division, see Akkach (2010, 9-11).

26. See Ibn Kannān al-Ṣalihịī (1992), and AlBadrī (2006). 
city, creating a complex network of water supplies. Running through the city, these rivers irrigated its numerous private and public gardens and terminated at the rich agricultural plains of al-Ghūta that provided the city with an abundance of vegetables and fruits. Rising over 1,000 meters above sea level, Damascus is embraced from the North-West by the lofty mount Qasyūn, at the foothill of which stood many of the city's most beautiful and most frequented gardens. Among the beauties of Damascus, Ibn Kannān alȘāliḥ̂̄ (d. 1740) wrote, was the Triumph Dome (Qubbat al-Nașr), a pavilion perched on the highest point on the Qasyūn foothill, from which one views the entire fabric of the city, through which the rivers appear as "threads of silver." (28)

A census taken at the turn of the seventeenth century indicates that Damascus was an expanding prosperous urban centre. It might have lost some of its trade powers with most of the European diplomatic missions being based in the northern city of Aleppo, however, Damascus remained a centre of attraction for its natural beauty and cosmopolitan lifestyle. The French traveller Jacques de Villamont was taken by the natural beauty and richness of Damascus, as he wrote: "It is a very large and very powerful city, built on a very beautiful and very rich plain, through which run two rivers ... that subdivide into an infinity of brooks that water delightful gardens ... Whosoever considers the beauty, situation, and richness of this city well would judge it paradise on earth not for the appearance of the city's buildings, but for the bounty of the land alone." (29) "The beauties of Damascus" (mahāsin al-Shām) became a popular genre among Damascene historians and scholars, whose accounts often include praise and admiration by the many eminent scholars who visited Damascus and experienced its beautiful gardens. In The Wine of Babel several poems by 'Abd al-Ghanī himself corroborate the visitors' observations. One opens with the following lines:

If you are in serious trouble and feeling uneasy, settle in the land of Shām and live in Damascus.

You will find your desire in it and all that you aspire for, you will even achieve renown and become eloquent in speech.

A town that rose above all towns in beauty, and grew in splendour and increased in glamour ...

If you are to passionately love a home town, this is the one for you, above all towns, that deserves to be loved and be enraptured with (30).

To enjoy their city's natural beauties, the Damascenes developed a sophisticated culture of recreation. They referred to this social practice as tanazzuh, literally "to distance oneself," a term that is commonly used today for "recreational outing," "picnicking," "leisurely walks," and "going on an excursion." According to the lexicographer Ibn Manẓūr, the original meaning of the word was to distance oneself from water and places of habitation, that is, cities and villages. But "lay people misplace things," he explains, "and are mistaken when they say: 'we went out natanazzah,' when they go out to gardens. They equate tanazzuh with going

27. For a general reference on the history of Damascus, see Gérard Degeorge, Damascus. 28. Ibn Kannān (1992, 1: 384-85).

29. Degeorge, Damascus, 177-78.

30. Al-Nābulusīin Al-Jundī, A., ed. (1988, 102).

31. Ibn Manẓūr, Lis̄̄n al-'Arab, N.Z.H. out to farms, parks, and gardens, whereas tanazzuh is to distance oneself from villages and water, and to be where there is no water or dew or a gathering of people, that is, at the edge of the desert."(31) Whatever the original meaning of the term might have been, for the Damascenes, lay and elite, the tannazuh meant one thing: to be in the city's mutanazzahāt, that is, the numerous landscaped and natural gardens, where water, shade, trees, flowers, cool breezes, food, and entertainment engaged the senses 
and offered pleasure, refreshment, and delight. Ibn Kannān devoted most of history al-Mawākib al-Islāmiyya to the beauties of Damascus, offering ample details on the city's recreational places and gardens, on Damascene horticulture, on species of trees and flowers, and on the socio-cultural practices associated with these places. He also cites numerous poetic representations of these places by renowned scholars, who invariably express attachment, delight, and joyful experiences.

'Abd al-Ghanī's anthology and other pre-modern accounts that describe the urbanity of Damascus refer to private and public gardens but without any clear formal distinction between them. Government-sponsored public gardens and recreational places, impressively large and elaborate, had a long history in Damascus. A two-line poem by the thirteenth century scholar Tāj al-Dīn al-Kindī (d. 1217), cited by Ibn Kannān, praises the Ayyūbid king Nūr al-Dīn for having dedicated al-Rabwa, one of the most beautiful recreational places on the banks of the Barada river, to the public. He wrote:

Surely when Nūr al-Dīn saw that in the gardens there are palaces for the rich.

He built the Rabwa as a lofty palace, an absolute recreational place for the poor (32).

The public recreational places were designed, urban sites with elaborate landscaping and commercial services. Ibn Kannān describes one named alJabha, also on the Barada river, as follows:

Al-Jabha: it is a square site, the size of two fiddan (about 8,500 $\mathrm{m}^{2}$ ), with shading trellises, but without mud on top, [built] in between willow, poplar, and walnut trees, and with many resting places surrounded by water canals from the four directions, as well as fountains and ponds with water-jets. Located on the side of the Barada river, one finds there waterwheels and shops for barbequed-meat sellers, cooks, butchers, snack sellers, drink sellers, fruit sellers, and herb sellers. There is also a mosque, two schools, and a lodge. There are waiters waiting to serve people; they have quilts, plates, pots, mattresses, and pillows for those who want to stay over (33).

Thirteenth century Andalusian scholar Ibn Sa'îd al-Ghirnāțị (d. 1286) described his delightful experiences of the Jabha as he wrote:

For the Jabha in my heart I have love, which I did not have for a beautiful face.

The water dances there with delightful pleasure, and the branches incline for the shaded shadow.

The sun wishes to stay over there, that is why she yellows at the time of setting (34).

As spaces of public sociability, leisure gardens, coffee houses, and even public baths were socially connected (35). After citing more poems describing joyful personal experiences of the Jabha, Ibn Kannān continues his description of the place, referring to two rivers that lie above it and from which water cascades down onto it. Above the rivers, he adds, there lies a public bath named Hammām al-Nuzha (Recreational Bath), next to which there is a maqșaf, which today means "canteen" or "refreshment shop." Ibn Kannān notes that the maqāṣif (pl. of maqșaf) were originally recreational places designated for the inactive soldiers and the unemployed (batțālinn) to pass time, "but now, they are called coffee houses (maqūhì, pl. of maqhā)." "In the past, before the coffee," he continues, "they used
33. Ibn Kannān (1992, 1: 222-25); see al-Badrī $(2006,79-80)$.

34. Ibn Kannān (1992, 1: 226).

35. On the emergence and socio-urban significance of the coffee-drinking and coffeehouses, see Encyclopaedia of Islam 2, "Kahwa;" Pascual (1995-96, 141-56); Hattox (1985); Çaksu (2007) and Mikhail (2007); Ellis (2004); and Hanna (2001, 91-101). 
to be called maqūșif."(36) He also notes that the person in charge of these apparently novel places, the maqūșift, "keeps cloaks, quilts, leather mats (used as tablecloths and game boards), even plates and spoons for those who want to eat. This does not exist anywhere other than Damascus." (37)

\section{Picturing the Landscape: Poetry and Gender}

Since pictographic representation of landscape was not a common practice in the Arab-Islamic tradition, poetry remained the main medium for picturing the landscape. Today's general understanding of "landscape" as "a view or prospect of rural scenery, more or less extensive, such as is comprehended within the scope of vision from a single perspective," is the legacy of the eighteenth-century picturesque tradition (38). This poses some conceptual and methodological difficulties. The concept of landscape, as a pictorial composition of natural or man-made scenery viewed from a vantage point and objectively disposed in the frame of a painting or the tourist's eye, is alien to the Arab-Islamic tradition, which developed no pictographic representations of nature and had no word for "landscape." In attempting to read and interrogate spatial practices using a foreign interpretive tool, one must remain conscious of the possible distortion involved. But since this study is not concerned with a broad theory of landscape perception, but rather with a historicised reading of expressions by a specific community sharing a distinct social structure, poetic sensibility, and horizon of expectations, the distortion that the term "landscape" inflicts on the study is marginal.

In The Wine of Babel, the poetic exchanges took place in specific natural and designed visual fields that are identified by three Arabic terms: bustān, hadī $q a$, and rawd da. With the little information available on the garden history of Damascus and greater Syria (Bilād al-Shām), it is difficult to identify the different formal characteristics, if any, that each term designates. Here, I loosely refer to these fields as "gardens" and "recreational places." While bustān and ḥadīqa are often used interchangeably, generally, bustān tends to refer more to open sites designated for agricultural purposes, whereas haqida refers more to enclosures designated for aesthetic purposes. Rawd a remains a vague term that can refer to both, as well as to undesigned natural settings. Hadĩga is the only term with visual connotations, as it shares with hadaqa, "iris," the same root, of which haddaqa means to "stare" at, fix one's "gaze" on, and "encircle" something (39). It is difficult to ascertain whether the original association between the eye and the garden was based on form or function. The etymology of the term, however, suggests that it was based on form, since a hadìqda, like an iris, was depicted as a planted circular enclosure conspicuously delineated from its arid surrounds (40).

Poetic representations of landscape were extensive in the Arabic-speaking Ottoman world, as talented poets and literary scholars entertained high social status. Poetic imageries, more fluid than graphic imagery, were nonetheless governed by the decorum of genre in terms of representational

36. Ibn Kannān (1992, 1: 229-30).

37. Ibn Kannān (1992, 1: 229).

38. The Macquarie Dictionary, "Landscape." On the picturesque tradition, see Andrews (1989).

39. Ibn Manẓūr, Lisān al-'Arab, H.D.Q.

40. Ibn Manẓūr, Lisān al-'Arab, H.D.Q. techniques and aesthetic conventions. They were also expressive of localised varied experiences. While romantic representation of nature has always been a main theme in Arabic poetry, those concerned with the beauties of Damascus, in general, and those by 'Abd al-Ghani in particular, have a specific flavour expressive of the aesthetic attitude of the Damascenes toward their own landscape. 
A garden in which the red anemone has blossomed, mimicked by the rosy cheek of the beloved.

One day, the beloved said to it, while on him blew the cool breeze and began to feel cold.

You stole my cheeks and forged my mole, and this is because your heart is black (41).

The desired yet unreachable imaginary beloved, with beautiful eyes and seductive glances, with slender body and delicate stature, who rejoices in ambivalence, and who is often portrayed in a masculine gender, is a governing theme of the genre that features prominently in The Wine of Babel (42). In fact, the first half of the anthology, most likely written by the youthful 'Abd al-Ghanī, is dominated by such amatory elegies and love poetry. Some of the poems were event or context related, yet others were not. He wrote:

The passionate lovers' eyelids are tired of your love, continuously, with much grief, are tearful.

A body, the sickness nearly effaced all of its features, so the events of its suffering can be seen on its sides.

Easy, O you, who has exceeded the limit in antipathy, dispassionately leaving my heart while it is earnestly attached (43).

In this frame of representation, femininity -subtle and ideal- always remains intangible. It hovers as a mysterious quality created solely for the suffering of passionate men, who seem unable to unite with the objects of their burning desires. The intangible yet highly desirable femininity renders her qualities ethereal and detached from the embodied reality, thereby allowing the poet to map them over his immediate objects of engagement. In The Wine of Babel, the objects of engagement were, of course, elements of the landscape. The Sufis excelled in this technique, especially in mapping feminine qualities over divinity. Ibn 'Arabī's Tarjumān al-Ashwāq is one of the finest examples of this genre (44). As a passionate admirer and defender of Ibn 'Arabī, 'Abd al-Ghanī was deeply influenced by the great master, yet it is important to note here that in The Wine of Babel he was certainly not following in the master's footsteps. The engrossing sensuality of 'Abd al-Ghanī's poetry was explicitly and unashamedly dedicated to earthly pleasure. His mystical poems were deliberately compiled in a separate anthology (45).

Within the governing decorum of the genre there are culturally-coded associations between elements of nature and elements of femininity that are expressive of the Damascene taste. For example, Damascus was famous for its red roses. Picturing the redness of the rose as mimicking the colour of the beloved's cheeks is a common theme in 'Abd al-Ghanī's imageries:

41. Al-Nābulusī in Al-Jundī, A., ed. $(1988,25)$.

42. The "beloved" in this widespread genre of poetry is not always a female; it often refers to young beautiful beardless boys. See Walter Andrew and Mehmet Kalpakli (2005); and Khaled El-Rouayheb (2005).

43. Al-Nābulusī in Al-Jundī, A., ed. $(1988,22)$.

44. Ibn ‘Arabī (1978).

45. I translated parts of 'Abd al-Ghani's famous mystical poem on truth, in Akkach (2005, 110-27)

46. Al-Nābulusī in Al-Jundī, A., ed. (1988, 143).
To my eyes was revealed a rose on a branch, red, like the cheek of my passionate lover.

Its whiteness in the middle of its redness has a glow, like a crescent moon of pearls in a sky of carnelians (46).

Another recurrent image depicts the subtle swaying of a branch by a gentle breeze as mimicking the delicate and seductive swaying of the beloved's body. In the following lines 'Abd al-Ghani adds to the natural aesthetics of the feminine body the likeness of the hip's curvature to the shape of a dune, and the blackness of the hair to the darkness of the night:

He visited me as the night was pulling its tail, in the likeness of full moon, too transcendent to be reached.

With a delicate body, he scored my heart by his sway, 
as the branch went on deliberately exposing his swaying.

When he appeared, we thought it was a crescent moon, one that from the sky of the heart never fades away.

A slender branch of a Ban tree, from his hip is the shade of a dune, A full moon, from his hair is the darkness of the night (47).

In several poems 'Abd al-Ghanī reveals the feminine body's main characteristics that were appreciated by Damascene men. They include detailed references to the figure, the face, the smile, the teeth, the eyes, the hair, the stomach, the hands, the curvature of the body, as well as to certain types of seductive looks, body movements, poses, and dispositions. They reveal a desire for the body to be slightly plump, the figure to be delicate, the eyes' white to be bright, the front teeth to be with a slight opening, the stomach to be flat, and the hips to be fleshy and round (48). Purity, softness, and delicacy, however, were the collective feminine qualities most repeatedly mapped over the landscape. Describing some of these feminine qualities, 'Abd al-Ghanī wrote:

Has soft fingers and pure cheek, so delicate that it almost gets wounded by quick-passing glances (49).

How do I rid myself of your eyes, how? while drawing on me the swords of coquetry and seduction (50).

Some poems expressed the sensuality of the femininity-landscape association through explicitly wild and erotic imageries:

A rose I came across in a garden, red on its fresh tender branch.

It looks like the cheek of the beloved, that is bleeding from excessive kissing and biting (51).

And:

I embraced him while the night's attire was let down; the more I kissed the more he smiled.

Until his chest absorbed mine in bonding, And the two hearts warmed up the cold-hearted (52).

Not all poems presented femininity as a lens to view the landscape, of course. There are many poems that describe specific places and elements of landscape design, particularly fountains, using a wide range of nongendered imagery and associations. The flickering of the sun's reflections on a running stream of water, for example, is often likened to a shining sword being drawn from its sheath. Describing a fountain in a garden setting, 'Abd al-Ghanī wrote:

A fountain with which the minds are dazzled, and the thoughts are perplexed trying to describe it.

47. Al-Nābulusīi in Al-Jundī, A., ed. (1988, 13).

48. See detailed descriptions in Al-Nābulusī, in Al-Jundī, A., ed. (1988, 155-58).

49. Al-Nābulusīi in Al-Jundī, A., ed. (1988, 121).

50. Al-Nābulusī in Al-Jundī, A., ed. (1988, 121).

51. Al-Nābulusī in Al-Jundī, A., ed. (1988, 143).

52. Al-Nābulusīin in Al-Jundī, A., ed. (1988, 188).
It looks like a gazing eyeball, an eye unable to sleep from the ecstasy of love.

Crying without having left her hometown one day, and without her family giving up their desires.

What a beautiful and well crafted pipe-work, within which the water rises up and descends down.

A mace of silver, under which, the water bubbles cast many circles (53).

In conclusion, the landscape sensibility and aesthetic attitude that The Wine of Babel reveals contrasts with those of the picturesque that developed in Europe around the same time. 'Abd al-Ghani and his group expressed no distinction in their appreciation of rural and urban landscape. Even as a traveller, 'Abd al-Ghanī revealed no conscious search for virgin nature, nor 
53. Al-Nābulusīi in Al-Jundī, A., ed. (1988, 127-28).

54. Al-Nābulusīi in Al-Jundī, A., ed. (1988, 121-22). did he seem to have an ideal landscape in mind. Engagement with native beauties and the sensuality of nature were always dictated by the state of the moment (hăl) as it revealed its workings through the poetic imagination of the group. Many gatherings were repeatedly held in the same place and the poetic expressions were always different. The Wine of Babel presented what the educated, cultured taste of the Damascene considered to be aesthetically pleasing: a dynamic and imaginative interplay between the self, the place, and the beloved, moulded within the decorum of Arabic poetry and the habitual exercise of comparison and association between femininity and landscape.

Be gentle with the branches of the Ruba, O breeze, because it is by passionate longing they are swaying.

Your wine has gone through them to intoxication, so that they began bending their straight figures.

We were in an intimate gathering place, whose air was freshened by delicious fragrances.

The water was flowing up and down, in a pool, spreading and throwing ordered pearls.

Rods of glass bent by a hand, made of pipes for the breeze to strike.

Underneath us was a brook of running water Flowing like a sharp-cutting sword...

What a day it was for us there, so delightful, in a gathering place like the gardens of paradise (54).

\section{MESİRE BAHÇELERİ, DÜNYEVİ ALIŞKANLIKLAR: OSMANLI ŞAM'INDA DİNLENCE KÜLTÜRÜ}

Mesire bahçeleri ve bu bahçelerle ilişkili dinlence kültürü Orta Doğu şehirlerindeki yaşamın ayrılmaz bir parçası olmuştur. Buna rağmen, Osmanlı vilayet merkezlerindeki kent peyzajı ve bununla ilişkili mekana ait uygulamalar üzerine pek az bulgu açığa çıkarılmıştır. Bunun sonucu olarak, toplum-kent hayatının bu cephesi üzerine bilgimiz sınırlı kalmıştır. Bu durum, temel olarak geleneksel tarihi kaynaklardaki kent peyajı üzerine bilgi yetersizliği ile on dokuz-yirminci yüzyıllardaki modern kentleşmenin yayılımı sırasında bahçelerin çoğunun kentlerin dokusundan yitmiş olmasından kaynaklanmıştır. Bu çalışma, on yedinci ve on sekizinci yüzyıllar Osmanlı Şam'ındaki mesire bahçeleri ve dinlence kültürünü yeni bir ışıkla aydınlatmayı dener. Konuyu sıra dışı bir kaynakla araştırır; bu kaynak öncü bir gizemci olan 'Abd al-Ghan̄̄ al-Nābulusî'nin şiir derlemesidir. Babil Şarabı adlı bu daha önce incelenmemiş kaynak, kent hayatının çehresini şiir ve diğer kayıtlarla neşeyle anlatarak sıradışı bir dindar şahsiyetin dinlence etkinliklerini belgeler. Onun notları bugün varolmayan pek çok bahçe ve dinlence yerinin ismini verirken, şiiri dönemin estetik duyarlılığını anlamamızı sağlar. Bu yazı, onun şiirinde açığa çıkan estetik duyarlılığa, bir yandan, özel görsel alanlar üzerine duygulandırıcı deneyimler ortaya çıartmak için şiirsel imgeler ve mecazi ifadelerin kullanılma yollarını; diğer yandan, Şam toplumunda eğitimli seçkinler arasında cinsiyetin doğaya ve peyzaja yönelik genel estetik tavrı belirlemede oynadı̆̆ı rolü araştırarak odaklanır. 


\section{REFERENCES}

AKKACH, S. (2005) The Poetics of Concealment: Al-Nabulusi's Encounter with the Dome of the Rock, Muqarnas 22; 110-27.

AKKACH, S. (2007) Abd al-Ghañ al-Näbulusĩ: Islam and the Enlightenment, Oneworld, Oxford.

AKKACH, S. (2010) Letters of a Sufi Scholar: The Correspondence of 'Abd alGhañ̄ al-Nābulusī (1641-1731), Brill, Leiden 2010.

AL-BADRĪ, A.B. (2006) Nuzhat al-Anām fì Maḥ̄āsin al-Shām, Dār al-Bashā'ir, Damascus.

AL-BUDAYRĪ (1997) Ḥawādith Dimashq al-Yawmiyya (Dar Sa'd al-Dīn, 2nd ed., Damascus.

AL-GHAZZĪ, M.K. (MS 281) “Al-Wird al-Unsī wa al-Wārid al-Qudsī fī Tarjamat al-Shaykh 'Abd al-Ghanī al-Nābulusī”, Zāhiriyya, Damascus.

AL-JUNDI, A., ed. (1988) Burj Bābel wa Shadwu al-Balābel, Dar al-Ma'rifa, Damascus.

AL-NĀBULUSĪ (1986) Diwān al-Ḥaqā'iq wa Majmū' al-Raqā'iq, Dār al-Jīl, Beirut.

AL-NĀBULUSĪ (2007) Ghāyat al-Maṭlūb fì Maḥabbat al-Maḥbūb, Dār Shahrazād al-Shām, Damascus.

AL-'ULABĪ, A. (1989) Kițaṭ Dimashq: Dirāsa Tārīkhiyya Shāmila (Dār alTabbā', Damascus.

ALDDIN, B. (1985) ‘Abdalganī an-Nābulusī (1143/1731): Oeuvre, vie et doctrine, PhD dissertation, Université de Paris I, 2 vols., Paris.

ANDREW, W. and KALPAKLI, M. (2005) The Age of the Beloved: Love and the Beloved in Early Modern Ottoman and European Culture and Society, Duke University Press, Durhan and London.

ANDREWS, M. (1989) The Search for the Picturesque: Landscape Aesthetics and Tourism in Britain, 1760-1800, Scolar, Aldershot.

ÇAKSU, A. (2007) Janissary Coffee Houses in Late Eighteenth-Century Istanbul, in Sajdi, D., ed. (2007) Ottoman Tulips, Ottoman Coffee: Leisure and Lifestyle in the Eighteenth Century, Tauris Academic Studies, London and New York.

EL-ROUAYHEB, K. (2005) Before Homosexuality in the Arab-Islamic World, 1500-1800, The University of Chicago Press, Chicago and London.

ELLIS, M. (2004) The Coffee House: A Cultural History, Weidenfield and Nicolson, London.

FITTER, C. (1995) Poetry, Space, Landscape: Toward a New Theory, Cambridge University Press, Cambridge.

GRAN, P. (1998) Islamic Roots of Capitalism: Egypt, 1760-1840, Syracuse University Press, Syracuse.

HAMADEH, S. (2008) The City's Pleasures: Istanbul in the Eighteenth Century, University of Washington Press, Seattle and London.

HANNA, N. (2001) Coffee and Merchants in Cairo 1580-1630, in Tuchscherer, M.,ed. (2001) Le commerce du café avant l'ère des 
plantations coloniales, Institut Français d'Archéologie Orientale, Cairo; 91-101.

HANNA, N. (2003) In Praise of Books: A Cultural History of Cairo's Middle Class, Sixteenth to Eighteenth Century, Syracuse University Press, Syracuse.

HANNA, N. and ABBAS, R., eds. (2005) Society and Economy in Egypt and the Eastern Mediterranean 1600-1900, The American University of Cairo Press, Cairo.

HATTOX, R. (1985) Coffee and Coffeehouses: The Origin of a Social Beverage in the Medieval Near East, University of Washington Press, Seattle and London.

HOURANI (1962) Arabic Thought in the Liberal Age, Oxford University Press, Oxford.

IBN ‘ARABĪ (1978) Tarjumān al-Ashwāq, Theosophical Publishing House, London.

IBN KANNĀN AL-ȘĀLIḤī (1992) Al-Mawākib al-Islamiyya fì al-Mamālik wa al-Maḥ̄āin al-Shāmiyya, 2 vols., Wizārat al-Thaqāfa, Damascus.

IBN MANẒŪR (nd.), Lisān al-'Arab al-Muḥiț, 3 vols., Dār Lisān al-'Arab, Beirut.

MIKHAIL, A. (2007) The Heart's Desire: Gender, Urban Space and the Ottoman Coffee House, in Sajdi, D., ed. (2007) Ottoman Tulips, Ottoman Coffee: Leisure and Lifestyle in the Eighteenth Century, Tauris Academic Studies, London and New York.

MUBAIDIN, M. (2009) Thaqāfat al-Tarfìh wa al-Madīna al-'Arabiyya fī alAzmina al-Ḥadìtha: Dimashq al-'Uthmāniyya, Arab Scientific Publishers, Beirut.

PASCUAL, J.P. (1995-6) Café et Cafés à Damas: Contribution à la Chronologie de Leur Diffusion au Xvième Siècle, Berytus Archaeological Studies 42 (1995-96) 141-56.

SAJDI, D., ed. (2007) Ottoman Tulips, Ottoman Coffee: Leisure and Lifestyle in the Eighteenth Century, Tauris Academic Studies, London and New York.

SIYYRIYEH, E. (2005) Sufi Visionary of Ottoman Damascus: 'Abd al-Ghanī alNābulusī, 1641-1731, RoutledgeCurzon, London.

VON SCHLEGELL, B. (1997) Sufism in the Ottoman Arab World: Shaykh 'Abd al-Ghanī al-Nābulusī (d. 1143/1731), PhD dissertation, University of California, Berkeley.

SAMER AKKACH; Ph.D.

Reader in Architectural History and Theory, and Founding Director of the Centre for Asian and Middle Eastern Architecture (CAMEA) at the University of Adelaide, Australia. His major works include Letters of a Sufi Scholar: The Correspondence of 'Abd al-Ghanī al-Nābulusī (Brill 2010), 'Abd al-Ghañ̄ al-Nābulusĩ: Islam and the Enlightenment (Oneworld 2007), and Cosmology and Architecture in Premodern Islam: An Architectural Reading of Mystical Ideas (SUNY 2005). 